\title{
The Impact of National Economic Development on the Shadow Economy
}

\author{
- Romualdas Ginevicius, Tomas Kliestik, Andrius Stasiukynas, \\ Karel Subajda
}

\begin{abstract}
A country's competitiveness depends primarily on its economic development which in turn is affected by a number of factors. Some of these, such as investment, favorable business conditions, legal environment, etc., promote economic development, while others, such as low labor productivity, insufficient staff qualification that fails to meet the requirements of the labor market, etc., slow down the pace of economic development. The latter category describes the phenomenon of the shadow economy (SE). Research into shadow economies is dominated by the analysis of the local impact factors. Nevertheless, the results of such analyses do not reveal the general patterns of the shadow economy, without the knowledge of which it is difficult to develop effective preventive measures. The basic determinants of the shadow economy must first and foremost reflect national economic development, as these particular determinants have the most significant impact on the size of the phenomenon of the shadow economy. National economic development can be expressed by employing various indicators, but recently it has most commonly been expressed by GDP per capita. GDP reflects national competitiveness, integrates a number of domestic factors, and is easily accessible and publicly available in national and international statistical sources. In addition, this indicator is calculated by employing a unified methodology, which makes it universal, allowing the comparison of countries in different situations. As presented in this article, the analysis of the relationship between economic development and the size of the shadow economy allows the division of all the EU member states into characteristic groups by the level of their economic development as well as size of the country's SE. Our research attempts to reveal the regularity of the above-mentioned relationship: the higher the level of national economic development, the lower the size of the shadow economy.
\end{abstract}

Keywords: macroeconomic, GDP per capita, shadow economy

JEL Classification: O11, M23, L13

Received: May, 2020

1st Revision: November, 2020

Accepted: November, 2020 


\section{INTRODUCTION}

Despite the fact that the shadow economy is one of the key obstacles to national economic development and thus to increasing competitiveness, the size of SE is still substantial in many localities. In some countries, it exceeds 30 percent of GDP per capita. This is partly because the nature and effects of the shadow economy are contradictory. Depending on psychological, cultural and other long-standing traditions, SE is sometimes seen not only as a harmful, but also as a partially tolerable phenomenon (Martínez-Rodriguez et al., 2020). The perspective depends on the prevailing public attitude, i.e. on how a society perceives the likelihood of illegal activities being detected and potentially punished. Public perceptions are also affected by such factors as a population's attitude towards public spending, confidence in a country's tax system, quality of public services, etc. When positive feedback is not ensured, the size of SE increases.

In any case, the size of SE depends exclusively on the effectiveness of preventive measures, which often prove not to be fully effective since the causes of the emergence and existence of this phenomenon are beyond the scope of these measures. To a large extent, determining this level of effectiveness is the goal of local impact factor analysis.

To increase the efficacy of such analyses, attempts are generally made to group the countries under consideration in terms of various aspects of their development. Such groupings make it possible to determine the size of the SE characteristic to various country groups. Such an approach undoubtedly contributes to a more accurate, albeit one-sided, assessment of the size of the SE, which in turn allows for the development of measures aimed at reducing the size of the $\mathrm{SE}$ in accordance with the situation in each country group. EU member states have been grouped according to the following criteria: the EU accession date (Schneider, 2015b; Tudose \& Clipa, 2016); regions (Tudose \& Clipa, 2016; Hudson et al., 2012; Hordnic \& Williams, 2016); national development level (Enste, 2018; Schneider, 2016; Eilat \& Zinnes, 2002); peculiarities of the economy (Williams, 2013; Blackburn et al., 2012; Vousinas, 2017), etc.

The size of an SE as determined by individual aspects of evaluation can be erroneous since the countries in a particular group may be evaluated in a favorable position with respect to one aspect, but unfavorably with respect to another. In other words, although such evaluation is necessary, it does not provide any generalized picture; this creates a situation which hiders the disclosure of the general SE patterns and formation of an effective SE reduction policy. Still, the basic causal SE determinants integrating the essential aspects of national development should include GDP (Moldan et al., 2012; Brizga et al., 2014; Jędrzejczak-Gas \& Barska, 2019; Kozyreva et al., 2017).

It therefore makes sense to focus specifically on the impact of GDP on the shadow economy. The use of this indicator, one which in a sufficiently objective way reflects national economic development as a whole, is also expedient, as information about its dynamics is easily available and publicly announced in both national and international statistical issues. In addition, GDP is estimated by following a uniform methodology, which makes it universal and allows for the comparison of different countries by the level of their economic development. 


\section{THE PHENOMENON OF THE SHADOW ECONOMY}

The shadow economy as a phenomenon is one which began to be studied by scientists and practitioners in the third and fourth decades of the 20th century with the onset of the Great Depression, but has not lost relevance till this day. Nevertheless, despite the relevance of this issue, no common terminology or concept defining the phenomenon of the shadow economy has thus far been agreed on either nationally or internationally (Anderberg, 2003; Asatiani \& Walenski, 2004; Rosser, 2006; Bajada, 2002; Feige, 2003; Fleming et al., 2000; Enste, 2003; Schneider, 2006a; Rosser et al., 2000). The content and structure of this phenomenon also remain vague. The lack of a universal understanding of the nature and classification of SE leads to a situation in which each researcher may propose a different definition of this phenomenon depending on the stated purpose of the research. Along these lines, the shadow economy has been defined by employing a number of various terms: underground, unofficial, informal, second, cash, parallel, illicit, illegal, irregular, hidden, unobserved, non-observed, unrecorded, alternative, subterraneous, occult, black economy, and so forth. The shadow economy is commonly assessed either on the basis of a single attribute, i.e. in a narrow sense (e.g. by the scale of smuggling), or in a broad sense covering all economic activity outside the law (e.g. tobacco and alcohol smuggling, fraud, prostitution, thefts, embezzlement, drug trafficking, arms trafficking, extortion, etc. (Genys, 2016; Schneider \& Buehn, 2016). The shadow economy has been explained by the following different approaches (Table 1).

Tab. 1 - Approaches explaining the shadow economy. Source: Genys (2016)

\begin{tabular}{|l|l|l|}
\hline No. & Explanatory approach & Content of the approach \\
\hline 1. & Statistical & $\begin{array}{l}\text { The part of a country's economic performance that is not } \\
\text { directly included in the calculations of the official GDP; on } \\
\text { the other hand, it is in fact included unofficially }\end{array}$ \\
\hline 2. & Legal & $\begin{array}{l}\text { All that is done to obtain financial and non-financial gains in } \\
\text { violation of legal provisions }\end{array}$ \\
\hline 3. & Budgetary & $\begin{array}{l}\text { The results of the regulated economy which are not account- } \\
\text { ed for since they are not declared or are concealed in order to } \\
\text { avoid a tax obligation or to obtain other illegal tax benefits }\end{array}$ \\
\hline
\end{tabular}

The methods for estimating the size of the shadow economy have been divided into three groups: direct, indirect and mixed.

The first group comprises the following SE estimation methods (Gasparèniene \& Remeikiené, 2016a; Georgiou, 2007; Herwartz et al., 2013; Williams, 2007): direct survey; direct data collection; the analysis of the results of tax inspections and other investigations, etc. examples include, for instance, a study of empty tobacco product packages (cigarette packs) commissioned by tobacco companies, research into the black alcohol market, etc.

The second group comprises the following shadow economy estimation methods: cash, national income and expenditure, real labor force, transactions, electric energy consumption research, 
etc. These methods are most common (Fethi et al., 2006; Gasparènienė \& Remeikiené, 2016b). The essence of the methods attributable to the third group is reflected in the name "mixed" itself, i.e. both direct and indirect shadow economy estimation methods are used in combination. The structure of the shadow economy estimation methods is depicted in Figure 1.

Direct methods:

Fig. 1 - The structure of shadow economy estimation methods. Source: Genys (2016)

Literature analysis indicates that even the authorities of the same country use different shadow economy estimation methods, which, in its turn, determines significant differences in the results (Gasparènienè \& Remeikienė, 2016a; Gasparènienè \& Remeikienė, 2016b).

The shadow economy functions not in an empty space. Its emergence and size are determined by a number of causal factors. It was found that the main causes of the shadow economy in the EU and some other countries include: tax burden, the scale of economic regulation, tax morale, the level of public trust in a country's government, unemployment and employment rates (Schneider, 2015a). It is considered that the above-mentioned factors are represented by such indicators as cash rate, GDP per capita, official labor force participation rate and others (Sinicakova \& Gavurova, 2017).

The biggest damage caused by the shadow economy is the decline in a budget revenue. Out of the above-mentioned causal factors, tax environment, or, in other words, tax burden, has the greatest impact on the size of the shadow economy. This circumstance is best illustrated by the Laffer curve depicted in Figure 2 (Williams \& Schneider, 2013). 


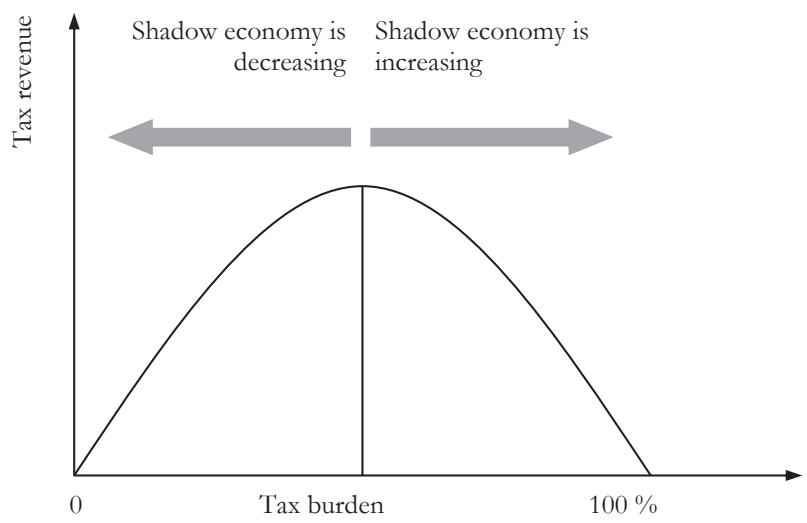

Fig. 2 - The impact of tax burden on the size of the national shadow economy. Source: Williams \& Schneider (2013)

On the other hand, the opinion on the exceptional impact of tax burden on the size of the shadow economy is equivocal. Some scientific studies and practical observations criticize it, although the significance of the impact itself is not argued (Bilan et al. 2017; Masood et al. 2017). The critical position concerning the impact of tax burden on the size of the shadow economy is based on the analysis of the current reality. For instance, the countries, such as Denmark, Finland, Sweden and some others, with high tax burden that amounts to nearly 52-55 percent of GDP are among the top ten states with the lowest size of the shadow economy (Krumplyte, 2011). The opposite situation is also not uncommon: the countries with relatively low tax burden tend to have particularly large shadow economies, for example, Sakartvelo, where the tax burden does not exceed 20 percent of GDP, but the size of the shadow economy amounts to over 60 percent of GDP.

In addition to tax burden, scholars emphasize tax morale as a particularly important determinant of the shadow economy. It is unequivocally considered that the countries with high tax morale tend to have lower levels of the shadow economy (Krumplyte், 2011).

Institutional quality is also treated as a significant causal determinant of the shadow economy, while labor market regulation as well as the quality of public sector services, social support systems, etc. are treated as less significant (Table 2).

Tab. 2 - Determinants of the shadow economy. Source: Schneider (2011)

\begin{tabular}{|l|l|l|}
\hline \multirow{2}{*}{ Determinants affecting the shadow economy } & \multicolumn{2}{|l|}{ Impact on the shadow economy (percent) } \\
\cline { 2 - 3 } & $\begin{array}{l}\text { The average result } \\
\text { of 12 studies under } \\
\text { consideration (tax } \\
\text { morale included) }\end{array}$ & $\begin{array}{l}\text { The average result of } \\
22 \text { studies under con- } \\
\text { sideration (tax morale } \\
\text { excluded) }\end{array}$ \\
\hline (1) Taxes and social insurance contributions & $35-38 \%$ & $45-52 \%$ \\
\hline (2) Institutional quality & $10-12 \%$ & $12-17 \%$ \\
\hline (3) Social support system & $5-7 \%$ & $7-9 \%$ \\
\hline (4) Labour market regulation & $7-9 \%$ & $7-9 \%$ \\
\hline
\end{tabular}




\begin{tabular}{|l|l|l|}
\hline (5) Public sector services & $5-7 \%$ & $7-9 \%$ \\
\hline (6) Tax morale & $22-25 \%$ & - \\
\hline Accumulated effect of all determinants & $84-98 \%$ & $78-96 \%$ \\
\hline
\end{tabular}

It should be noted that the studies addressing the issues of the shadow economy are not yet comprehensive because many questions have not still been answered. Given the importance of the issue, the current situation calls for more comprehensive in-depth research to reveal the regularities of the shadow economy and at the same time, to provide effective measures for reduction of the size of this phenomenon.

\section{METHODOLOGIES FOR ASSESSMENT OF THE IMPACT OF NATIONAL ECONOMIC DEVELOPMENT ON THE SIZE OF THE SHADOW ECONOMY}

In order to identify the changes in the size of the shadow economy, an appropriate research design needs to be selected. Literature analysis helped to identify the main causal factors of the shadow economy, including GDP per capita. The authors of this article, however, consider that aligning GDP with other causal factors is methodologically inadequate because GDP is incomparably more complex compared to other proposed indicators. What is more, GDP essentially integrates some other indicators that are local in their sense and represent much less complex factors. It is, therefore, expedient to look specifically at the impact of GDP on the shadow economy (Chursan, 2013; Čiegis et al., 2010; Bolcarova \& Kološta, 2015; Babu \& Datta, 2015; Molly, 2018; Moldan et al., 2012; Brizga et al., 2014; Jędrzejczak-Gas \& Barska, 2019; Huttmanová \& Valentiny, 2019).

Statistical sources show that the countries where the level of economic development is high, for instance, Austria, Denmark, the Netherlands, Finland, Sweden or Germany, tend to have a lower size of the shadow economy. Many literature sources indicate GDP per capita as an indicator representing national economic development. It is considered that the changes in this indicator sufficiently objectively reflect the level and success of national economic development (Chursan, 2013; Čiegis et al., 2010; Bolcarova \& Kološta, 2015; Babu \& Datta, 2015; Molly, 2018; Gasparènienė \& Remeikienè, 2016b; Van de Bergh, 2009; Brizga et al., 2014; Jędrzejczak-Gas \& Barska, 2019; Huttmanová \& Valentiny, 2019; Moldan et al., 2012). It is also important to note that the information on GDP per capita is easily available and publicly announced in both national and international statistical issues and databases (Medina \& Schneider, 2017). This indicator is estimated according to a unified methodology, which makes it universal and allows to compare countries by the level of their national economic development.

Another indicator required is one that would reflect the size and trends of the shadow economy. The basic requirements for this indicator can be defined as follows: firstly, it must adequately reflect the current size of the shadow economy and the changes in it; secondly, the relevant data must be easily available.

A literature analysis shows that the size of the shadow economy as percentage of GDP per capita 
can serve as the most reliable indicator (Wu \& Schneider, 2019). The assessment of the dependency between variables (national economic development and the size of the shadow economy) was made by correlation coefficient. The countries of the European Union were used as a sample for the research. The strength of correlation was calculated, and its statistical significance was tested. The strength of the dependency of correlation coefficient is as follows:

$0.0<$ the value of the correlation coefficient $\leq 0.3 \quad$ weak dependence

$0.3<$ the value of the correlation coefficient $\leq 0.8 \quad$ medium dependence

$0.8<$ the value of the correlation coefficient $\leq 1.0 \quad$ strong dependence

An objective assessment of the trends of the shadow economy requires a global approach, i.e. a global context analysis that would allow the formation of particular country groups, and thus providing a way to learn what impact the level of regional economic development has on the size of the shadow economy. With the data on both national GDP and the size of the shadow economy as a percentage of GDP per capita, the links between these two indicators can be researched by employing correlation analysis.

\section{ANALYSIS OF THE IMPACT OF NATIONAL ECONOMIC DEVEL- OPMENT ON THE SIZE OF THE SHADOW ECONOMY}

Figure 3 reveals the tendency of the size of the shadow economy in the countries of Central and East Europe to be considerably lower than in Southern countries. In other words, the size of the shadow economy increases as we move farther away from Europe.

Next, it is purposeful to look at the size of SE in the EU in the global context, which is depicted in Appendices 1-3. EU member states record a much lower size of shadow economy in comparison to other regions worldwide.

\begin{tabular}{|c|c|c|c|c|}
\hline & & \multicolumn{3}{|c|}{ Country's level of economic development } \\
\hline & & $2-25$ & $25-45$ & $>45$ \\
\hline \multirow{3}{*}{ 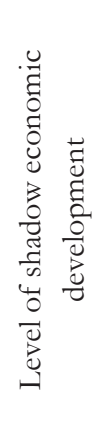 } & $\stackrel{\overbrace{}}{\wedge}$ & $\begin{array}{l}\text { Spain, Cyprus, } \\
\text { Greece, Hungary, } \\
\text { Eroatia, Bulgaria, } \\
\text { R@mania, Slovenia }\end{array}$ & & Italy \\
\hline & 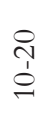 & $\begin{array}{l}\text { Portugal, Czechia, } \\
\text { Estonia Lithuania, } \\
\text { Latvia, Poland }\end{array}$ & $\begin{array}{l}\text { Finland, Belgium, } \\
\text { France }\end{array}$ & $\begin{array}{l}\text { Luxembourg, } \\
\text { Denmark, Sweden }\end{array}$ \\
\hline & $\frac{0}{\stackrel{1}{0}}$ & & $\begin{array}{l}\text { Netherlands, } \\
\text { Austria. } \\
\text { Germany, UK }\end{array}$ & Ireland \\
\hline
\end{tabular}

Fig. 3 - Situation of EU member states in terms of the ratio of GDP per capita (the level of national economic development) to the size of the shadow economy. Source: own research 
Figure 3 indicates that all EU member states can be divided into two levels according to their ratio of GDP per capita to the size of the shadow economy. The matrix above visually reflects the situation in each of the EU member states and highlights the nature of the relationship between the size of the shadow economy and national economic development. On the other hand, the comparison does not rank the states in terms of the particular issue under consideration. For this purpose, each sector in Figure 3 is given a score depending on the level of GDP per capita and the size of the shadow economy. The general situation in EU member states is reflected by the product of the estimates, a factor representing the level of GDP per capita and the size of the shadow economy (the higher the estimate, the worse the situation). In this case, the general situation in a state is reflected by the product of the scores representing the level of GDP and the size of the shadow economy, respectively.

The picture of the impact of economic development in EU member states on the size of the shadow economy is clearly depicted by the groups of the countries formed based on the ratio of their average size of the shadow economy to average GDP and a graphical depiction of this ratio. An arrangement of the EU member states in three groups by the size of the SE $(0-10 \%$; $10-20 \%$, and $20 \%$ or more) revealed that the average size of the SE in the first group amounts to 8.81 percent, while GDP averages 42.98 thousand EUR; in the second group, the size of the SE and GDP amount to 14.9 percent and 25.82 thousand EUR, respectively; in the third group to 23.97 percent and 15.53 thousand EUR.

Illustrated in Figure 4, the impact of national economic development on the size of the shadow economy was also confirmed after a correlation analysis, which revealed that the relationship between the variables under consideration is very tight since the correlation coefficient was equal to 0.76 (medium dependence). The significance of the gained correlation was tested. The null hypothesis (no relation between the variables) was rejected based on the computed p-value (0.003), thus the alternative hypothesis of significance between the variables can be confirmed.

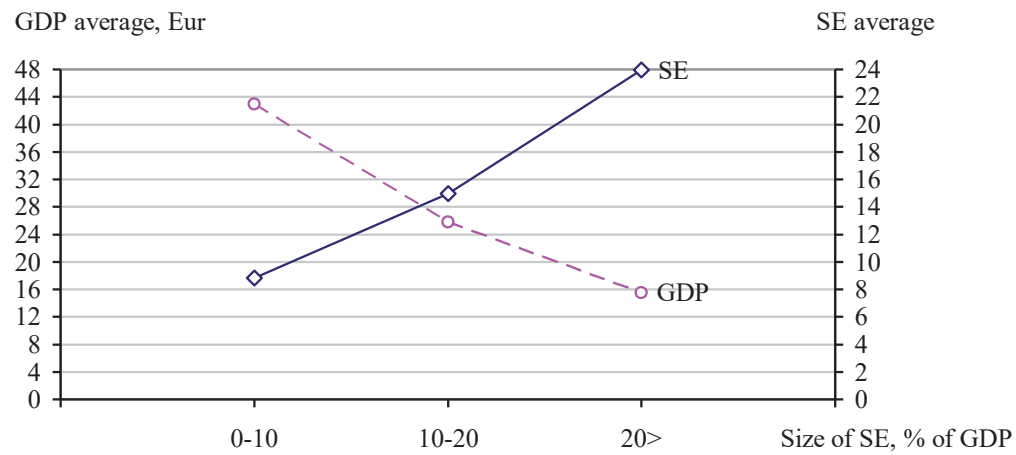

Fig. 4 - Nature of the impact of national economic development on the size of the shadow economy in the EU. Source: own research 
Figure 4 allows us to draw some conclusions and put forth some generalizations. Firstly, two directions for reduction of the size of the shadow economy - factual and strategical - can be distinguished. The former comprises current and operational measures, the content of which is revealed by the shadow economy determinants depicted in Table 2, while the latter covers the key measures that form the basic objective presumptions and preconditions for reduction of the shadow economy. Thus, in order to fundamentally resolve the problem of defining the shadow economy, efforts must be primarily directed to the acceleration of national economic development through promotion of investment, maintaining a business-friendly environment, and so forth.

\section{DISCUSSION}

A country's shadow economy is the result of the interaction between its socio-economic development and long-standing psychological and cultural factors. Some of these factors can only be perceived and recognized as influential with regard to the shadow economy and competitiveness, but they cannot be substantially affected, at least not in the short run. These issues can be referred to in terms of a problem of population's mentality. A pragmatic way of dealing with the problem of the shadow economy, i.e. reducing the size of this phenomenon, is the promotion of socio-economic development. When an economy is growing, improving social conditions not only reduce the size of the SE, but also raise a country's competitiveness and, most importantly, help to form negative public attitudes towards the SE. This assumption is very clearly confirmed by a number of sets of empirical results, i. e. with the growth of economic prosperity, the size of an SE decreases (Rutkauskas \& Stasytyte, 2020).

The impact of social factors on the size of an SE should be given high priority as research in this area is further expanded and deepened, but such research is rarely conducted at all. Meanwhile, inadequate conditions regarding housing, health care and social welfare generates tolerance for such negative societal phenomena as bribery, embezzlement, corruption and other ways of earning illicit profits. The difficulties of such research lie in the fact that the above-mentioned social factors are usually challenging to formalize. Thus, it is difficult to detect the relationship between these factors and the SE. The theory of expert evaluation may offer a solution to this problem.

The main conclusion that follows from this research is that in order to purposefully manage the process of the SE reduction it is necessary to reject the analysis of local level determinants of the $\mathrm{SE}$ and to embrace the analysis of the fundamental factors integrating the above-mentioned local level determinants, following which the analysis of the complex impact of these fundamental factors can be undertaken.

Our results are compared to those of The European Bank for Reconstruction and Development, which provides the following categorization of countries by regions (Table 3). 
Tab. 3 - Categorization of countries by regions provided by the European Bank for Reconstruction and Development. Source: own research

\begin{tabular}{|c|c|c|c|c|c|}
\hline \multicolumn{2}{|c|}{ Region } & \\
\hline $\begin{array}{c}\text { East Europe } \\
\text { End }\end{array}$ & $\begin{array}{c}\text { Central Eu- } \\
\text { rope and Baltic } \\
\text { States }\end{array}$ & $\begin{array}{c}\text { East Europe } \\
\text { and Caucasus }\end{array}$ & Central Asia & $\begin{array}{c}\text { Eastern and } \\
\text { Southern } \\
\text { Mediterrane- } \\
\text { an countries }\end{array}$ & Others \\
\hline Albania & Croatia & Armenia & Kazakhstan & Egypt & Russia \\
\hline $\begin{array}{c}\text { Bosnia and } \\
\text { Herzegovina }\end{array}$ & $\begin{array}{c}\text { Czech Repub- } \\
\text { lic }\end{array}$ & Azerbaijan & Kyrgyzstan & Jordan & Turkey \\
\hline Cyprus & Estonia & Belarus & Mongolia & Lebanon & \\
\hline Macedonia & Hungary & Georgia & Tajikistan & Morocco & \\
\hline Greece & Latvia & Moldova & Turkmenistan & Tunisia & \\
\hline Kosovo & Lithuania & Ukraine & Uzbekistan & & \\
\hline Montenegro & Poland & & & & \\
\hline Romania & Slovakia & & & & \\
\hline Serbia & Slovenia & & & & \\
\hline
\end{tabular}

The size of SE over the period 2006-2015 varies from region to region as well as from country to country. The largest size of the shadow economy was recorded in the Central Asian region - 30.3\%, then in Eastern and Southern Mediterranean countries (27.54\%), South and East Europe $(22.63 \%)$, East Europe and Caucasus (19.04\%), and Central Europe with the Baltic States $(13.5 \%)$. Thus, the size of the SE in Central Asia was 2.25 times higher than that in Central Europe with the Baltic States.

Within particular regions, the size of the shadow economy in some countries differs in comparison to other countries in the same region. For instance, the average for the countries of Central Asia amounts to 30.36 percent of GDP, while for Mongolia it amounts to nearly 14 percent; the average for Eastern and Southern Mediterranean countries amounts to 27.54 percent, while for Jordan it aggregates to nearly 14 percent.

\section{CONCLUSIONS}

The shadow economy has been for many years a phenomenon observed in virtually all countries. It manifests itself as an obstacle to national economic development, reducing its competitiveness. Nevertheless, despite the relevance of this issue, no common terminology or concept defining the phenomenon of the shadow economy has thus far been agreed upon either nationally or internationally. The results of our research allow us to distinguish two directions for the reduction of the size of the shadow economy - factual and strategical. The former comprises current and operative measures, such as tax burden reduction, tax morale promotion, institutional quality improvement, labor market regulation balancing, etc., while the latter primarily covers the accel- 
eration of national economic development. The largest portion of current studies can be assigned exclusively to the first category, since they address only local measures that certainly contribute to reduction of the size of the shadow economy, but do not explain how to solve this problem in principle because they do not reveal the general patterns of the SE. The impact of local level factors on SE is integrated into GDP per capita, which fairly objectively reflects national economic development as a whole. The authors of this article found some regularities in the relationship between GDP and the size of the SE. First, there are significant differences among the size of the SE in different regions and countries worldwide. Second, our correlation analysis of the dependence of the size of the SE on GDP showed that an elastic relationship exists between the variables: as GDP grows, the size of the SE decreases with a statistically significant correlation coefficient of $\mathrm{r}=0.76$.

Continuing research in this direction, it would be purposeful to quantify how the size of the SE depends on certain determinants that are difficult to formalize, such as reduction or increase in tax burden, quality of the work of public institutions, situation in the labor market, market regulation, etc., as well as on the social nature of the determinants. On the other hand, these and similar studies may be limited by the unavailability of relevant data, difficulties in quantitatively evaluating the SE determinants that are difficult to formalize, etc.

In order to develop a fundamental solution to eliminating the putative need for an SE, efforts must be directed primarily to the acceleration of national economic development through the promotion of investment and a business-friendly environment as well as other positive incentivization initiatives.

\section{References}

1. Anderberg, D. (2003). Insiders, Outsiders, and the Underground Economy, University of London, Department of Economics. CESifo Working Paper Series from CESifo Group Munich 1048. London, United Kingdom: University of London, Department of Economics. Retrieved from https://www.cesifo-group.de/DocDL/cesifo1_wp1048. pdf (application)

2. Asatiani, T., \& Walenski, M. (2004). Shadow economy in Georgia. Economy of Georgia, 18.

3. Babu, S., \& Datta, S. K. (2015). Revisiting the link between socio-economic development and environmental status indicators-focus on panel data. Environment, Development and Sustainability, 17 (3), 567-586.

4. Bajada, C. (2002). Australia's cash economy: A troubling issue for policymakers. Burlington. VT: Ashgate. https://doi.org/10.4324/9781315187372

5. Blackburn, K., Bose, N., \& Capasso, S. (2012). Tax evasion, the underground economy and financial development. Journal of Economic Behavior \& Organization, 83 (2), 243-253. https://doi.org/10.1016/j.jebo.2012.05.019

6. Bilan, Y., Gavurova, B., Stanislaw, G., \& Tkacova, A. (2017). The Composite Coincident Indicator (CCI) for Business Cycles. Acta Polytechnica Hungarica, 14 (7), 71-90. https://doi.org/10.12700/aph.14.7.2017.7.5

7. Bolcarova, P., \& Kološta, S. (2015). Assessment of sustainable development in the EU27 using aggregated SD index. Ecological Indicators, 48, 699-705. 
8. Brizga, J., Mishchuk, Z., \& Golubovska-Onisimova, A. (2014). Sustainable consumption and production governance in countries in transition. Journal of Cleaner Production, 63, 45-53. https://doi.org/10.1016/j.jclepro.2013.06.011

9. Chursan, S. (2013). Assessing the Sustainable Development in Thailand. Procedia. Environmental Sciences, 17, 611-619.

10. Čiegis, R., Ramanauskienè, J., \& Šimanskienė, L. (2010). Lietuvos regionų darnaus vystymosi vertinimas - Assessment of the sustainable development in Lithuanian regions. Klaipeda: Klaipèda University publishing.

11. Eilat, Y., \& Zinnes, C. (2002). The Shadow Economy in Transition Countries: Friend or Foe? A Policy Perspective. World Development, 30 (7), 1233-1254. https://doi.org/10.1016/S0305-750X(02)00036-0

12. Enste, D. H. (2003). The Shadow Economy and institutional change in transition countries, in the informal economy in the EU Accession Countries. IZA World of Labor.

13. Enste, D. H. (2018). The shadow economy in industrial countries. https://wol.iza.org/ uploads/articles/457/pdf/shadow-economy-in-industrial-countries.pdf? $\mathrm{v}=1$. https://doi.org/10.15185/izawol.127.v2

14. Feige, E. L. (2003). Defining and estimating underground and informal economies: The new institutional economics approach. Development and Comp System 03 12003, EconWPA.

15. Fethi, M. D., Fethi, S., \& Katircioglu, S. T. (2006). Estimating the size of the Cypriot underground economy: A comparison with European experience. International Journal of Manpower, 27 (6), 515-534. https://doi.org/10.1108/01437720610690464

16. Fleming, M. H., Roman, J. K., \& Farrell, G. (2000). The Shadow Economy. Journal of International Affairs, 53 (2), 387-412.

17. Gaspareniené, L., \& Remeikienè, R. (2016a). The methodologies of shadow economy estimation in the world and in Lithuania: whether the criterions fixing digital shadow are included? 3rd Global conference on Business, ecoeconomics, management and tourism, 39, 753-760. Rome: Procedia. Economics and finance.

18. Gasparėniené, L., \& Remeikienė, R. (2016b). Shadow economy estimation methods: Digital shadow economy assessment aspect. Business and management: the 9th international scientific conference, 1-8. Vilnius: Technika.

19. Genys, N. (2016). Šešèlinè ekonomika. Pokyčiai per dešimtmetį. Retrieved 0106,2020 , from https://www.vdi.lt/PdfUploads/seselinEkonomika2016.pdf

20. Georgiou, G. M. (2007). Measuring the size of the informal economy: a critical review. Central Bank of Cyprus. Retrieved from http://www.centralbank.gov.cy/media/pdf/ npwpe_ no1_052007__.pdf

21. Herwartz, H., Tafenau, E., \& Schneider, F. (2013). One share fits all? Regional variations in the extent of the shadow economy in Europe. Regional Studies, 1575-1587. https://doi.org/10.1080/00343404.2013.848034

22. Horodnic, I. A., \& Williams, C. C. (2016). An evaluation of the shadow economy in Baltic states: a tax morale perspective. International Journal of Entrepreneurship and Small Business, 28 (2), 339-358. https://doi.org/10.1504/IJESB.2016.076638 
23. Hudson, J., Williams, C., Orviska, M., \& Nadin, S. (2012). Evaluating the Impact of the Informal Economy on Businesses in South East Europe: Some Lessons from the 2009 World Bank Enterprise Survey. The South East European Journal of Economics and Business, 7(1): 99-110.

24. Huttmanová, E., \& Valentiny, T. (2019). Assessment of the Economic Pillar and Environmental Pillar of Sustainable Development in the European Union. European Journal of Sustainable Development, 8 (2), 289-298. https://doi.org/10.14207/ejsd. 2019.v8n2p289

25. Jędrzejczak-Gas, J., \& Barska, A. (2019). Assessment of the Economic Development of Polish Regions in the Context of the Implementation of the Concept of Sustainable Development Taxonomic Analysis. European Journal of Sustainable Development, 8 (5), 222-233. https://doi.org/10.14207/ejsd.2019.v8n5p222

26. Kozyreva, O., Sagaidak-Nikituk, R., \& Demchenko, N. (2017). Analysis of the SocioEconomic Development of Ukrainian Regions. Baltic Journal of Economic Studies, 3 (2), 51-58. http://dx.doi.org/10.30525/2256-0742/2017-3-2-51-58

27. Krumplyte, J. (2010). Evaluation of the extent of the shadow economy. Doctoral dissertation. Vilnius: Technika.

28. Martínez-Rodriguez, M., Callejas-Albiñana, F. E., \& Callejas-Albiñana, A. I. (2020). Economic and socio-cultural drivers of necessity and opportunity entrepreneurship depending on the business cycle phase. Journal of Business Economics and Management, 21 (2), 373-394. https://doi.org/10.3846/jbem.2020.11848

29. Masood, O., Aktan, B., Gavurova, B., Fakhry, B., Tvaronaviciene, M., \& Martinkute-Kauliene, R. (2017). The impact of regime-switching behaviour of price volatility on efficiency of the US sovereign debt market. Economic Research-Ekonomska Istrazivanja, 30(1), 1865-1881. https://doi.org/10.1080/1331677X.2017.1394896

30. Medina, L., \& Schneider, F. G. (2017). Shadow Economies around the World: New Results for 158 Countries Over 1991-2015 CESifo Working Paper Series No. 6430. Retrieved from SSRN: https://ssrn.com/abstract=2965972

31. Moldan, B., Janoušková, S., \& Hák, T. (2012). How to understand and measure environmental sustainability: Indicators and targets. Ecological Indicators, 17, 4-13. https://doi.org/10.1016/j.ecolind.2011.04.033

32. Molly, K. M. (2018). Regional differences in Slovenia from the viewpoint of achieving Europe's sustainable development. Acta Geografica Slovenia, 58 (2), 31-46. https://ojs.zrc-sazu.si/ags/article/view/3309/4756

33. Rosser, J. B. (2006). Book's (Schneider, F.; Enste, D. H. Shadow Economy: an International Survey). https://doi.org/10.1017/CBO9780511493591

34. Rosser, J. B., Rosser, M. V., \& Ahmed, E. (2000). Income Inequality and the Informal Economy in Transition Economies. Journal of Comparative Economics, 28 (1), 156-171. https://doi.org/10.1006/jcec.2000.1645

35. Rutkauskas, A. V., \& Stasytytè, V. (2020). Stochastic informative expert system for investment. Journal of Business Economics and Management, 21 (1), 136-156. https://doi.org/10.3846/jbem.2020.11768 
36. Schneider, F. (2006a). Shadow Economies and Corruption All Over the World: What do We Really Know? IZA Discussion Paper No. 2315.

37. Schneider, F. (2006b). Shadow economies around the world: what do we really know? Working Paper No 0617.

38. Schneider, F. (2011). The Shadow Economy and Shadow Economy Labour Force: What do we (not) know? Discussion paper No. 5769. http://ftp.iza.org/dp5769.pdf

39. Schneider, F. (2015a). Estimating the size of the shadow economy in the Czech Republic and her Neighbouring countries: Last Results for 2015. Slides.

40. Schneider, F. (2015b). Size and development of the shadow economy of 31 European and 5 other OECD countries from 2003 to 2015: different developments? Journal of Self-Governance and Management Economics, 3 (4), 7-29.

41. Schneider, F. (2016). Estimating the Size of the Shadow Economies of Highly-developed Countries: Selected New Results. Retrieved from http://www.cesifo-group.info/DocDL/ olice-report-2016-4-schneider-december.pdf

42. Schneider, F., \& Buehin, A. (2016). Estimating the size of the shadow economy: methods, problems and open questions. Retrieved 01 03, 2020. http://www.economics.jku.at/ papers/2013/wp1320.pdf

43. Sinicakova, M., \& Gavurova, B. (2017). Single Monetary Policy versus Macroeconomic Fundamentals in Slovakia. Ekonomicky casopis, 65(2), 158-172.

44. Tudose, B. M., \& Clipa, R. I. (2016). An analysis of the shadow economy in EU countries. CES Working Papers, 8 (2), 303-312. Retrieved from http:/www.ceswp.uaic.ro/articles/ CESWP2016_VIII2_TUD.pdf

45. Van den Bergh, J. C. (2009). The GDP paradox. Journal of Economic Psychology, 30, 117-135.

46. Vousinas, G. L. (2017). Shadow economy and tax evasion. The Achilles heel of Greek economy. Determinants, effects and policy proposals. Journal of Money Laundering Control, 20 (4), 386-404. https://doi.org/10.1108/JMLC-11-2016-0047

47. Williams, C. C. (2007). Small business and the informal economy: evidence from the UK. International Journal of Entrepreneurial Behaviour \& Research. 13 (6), 349-366.

48. Williams, C. C. (2013). Out of the shadows: a classification of economies by the size and character of their informal sector. Work, Employment and Society, 28 (5), 735-753. Retrieved from https://doi.org/10.1177/0950017013501951

49. Williams, C. C., \& Schneider, F. (2013). The Shadow economy. The institute of Economic Affairs.

50. Wu, D. F., \& Schneider, F. (2019). Nonlinearity between the shadow economy and level of development. International Monetary Fund WP/19/48. 


\section{Contact information}

Prof. Dr. Habil Romualdas Ginevicius

Vilnius Gediminas Technical University

Faculty of Business Management

Institute of Dynamic Management

Lithuania

E-mail: romualdas.ginevicius@vgtu.lt

ORCID: 0000-0003-2067-4398

Prof. Ing. Tomas Kliestik, PhD.

University of Žilina

Faculty of Operation and Economics of Transport and Communications

Department of Economics

Slovakia

E-mail:tomas.kliestik@fpedas.uniza.sk

ORCID: 0000-0002-3815-5409

Dr. Andrius Stasinkynas

Kazimieras Simonavicius University

Business School

Lithuania

E-mail: andrius@snowarena.lt

Assoc. Prof. Karel Subajda

Brno Technical University

Faculty of Civil Engineering

Czech Republic

E-mail:subajda.k@fce.vutbr.cz.

ORCID: 0000-0001-7842-6966 


\section{APPENDIX 1}

The dynamics of the shadow economy in EU-15 (as percentage of GDP) (source: www.Eurostat. com)

\begin{tabular}{|c|c|c|c|c|c|c|c|c|c|c|c|c|c|}
\hline State & 2003 & 2004 & 2005 & 2006 & 2007 & 2008 & 2009 & 2010 & 2011 & 2012 & 2013 & 2014 & 2015 \\
\hline $\begin{array}{l}\text { Lu- } \\
\text { xem- } \\
\text { bourg }\end{array}$ & 9.8 & 9.8 & 9.9 & 10.0 & 9.4 & 8.5 & 8.8 & 8.4 & 8.2 & 8.2 & 8.0 & 8.1 & 8.3 \\
\hline $\begin{array}{l}\text { Aus- } \\
\text { tria }\end{array}$ & 10.8 & 11.0 & 10.3 & 9.7 & 9.4 & 8.1 & 8.5 & 8.2 & 7.9 & 7.6 & 7.5 & 7.8 & 8.2 \\
\hline UK & 12.2 & 12.3 & 12.0 & 11.1 & 10.6 & 10.1 & 10.9 & 10.7 & 10.5 & 10.1 & 9.7 & 9.6 & 9.4 \\
\hline $\begin{array}{l}\mathrm{Ne}- \\
\text { ther- } \\
\text { lands }\end{array}$ & 12.7 & 12.5 & 12.0 & 10.9 & 10.1 & 9.6 & 10.2 & 10.0 & 9.8 & 9.5 & 9.1 & 9.2 & 9.0 \\
\hline France & 14.7 & 14.3 & 13.8 & 12.4 & 11.8 & 11.1 & 11.6 & 11.3 & 11.0 & 10.8 & 9.9 & 10.8 & 12.3 \\
\hline Ireland & 15.4 & 15.2 & 14.8 & 13.4 & 12.7 & 12.2 & 13.1 & 13.0 & 12.8 & 12.7 & 12.2 & 11.8 & 11.3 \\
\hline $\begin{array}{l}\text { Ger- } \\
\text { many }\end{array}$ & 17.1 & 16.1 & 15.4 & 15.0 & 14.7 & 14.2 & 14.6 & 13.9 & 13.2 & 12.9 & 12.4 & 12.2 & 12.2 \\
\hline $\begin{array}{l}\text { Den- } \\
\text { mark }\end{array}$ & 17.4 & 17.1 & 16.5 & 15.4 & 14.8 & 13.9 & 14.3 & 14.0 & 13.8 & 13.4 & 13.0 & 12.8 & 12.0 \\
\hline $\begin{array}{l}\text { Fin- } \\
\text { land }\end{array}$ & 17.6 & 17.2 & 16.6 & 15.3 & 14.5 & 13.8 & 14.2 & 14.0 & 13.7 & 13.3 & 13.0 & 12.9 & 12.4 \\
\hline $\begin{array}{l}\text { Swe- } \\
\text { den }\end{array}$ & 18.6 & 18.1 & 17.5 & 16.2 & 15.6 & 14.9 & 15.4 & 15.0 & 14.7 & 14.3 & 13.9 & 13.6 & 13.2 \\
\hline $\begin{array}{l}\text { Belgi- } \\
\text { um }\end{array}$ & 21.4 & 20.7 & 20.1 & 19.2 & 18.3 & 17.5 & 17.8 & 17.4 & 17.1 & 16.8 & 16.4 & 16.1 & 16.2 \\
\hline $\begin{array}{l}\text { Portu- } \\
\text { gal }\end{array}$ & 22.2 & 21.7 & 21.2 & 20.1 & 19.2 & 18.7 & 19.5 & 19.2 & 19.4 & 19.4 & 19.0 & 18.7 & 17.6 \\
\hline Spain & 22.2 & 21.9 & 21.3 & 20.2 & 19.3 & 18.4 & 19.5 & 19.4 & 19.2 & 19.2 & 18.6 & 18.5 & 18.2 \\
\hline Italy & 26.1 & 25.2 & 24.4 & 23.2 & 22.3 & 21.4 & 22.0 & 21.8 & 21.2 & 21.6 & 21.1 & 20.8 & 20.6 \\
\hline Greece & 28.2 & 28.1 & 27.6 & 26.2 & 25.1 & 24.3 & 25.0 & 25.4 & 24.3 & 24.0 & 23.6 & 23.3 & 22.4 \\
\hline $\begin{array}{l}\text { EU-15 } \\
\text { avera- } \\
\text { ge }\end{array}$ & 17.8 & 17.4 & 16.9 & 15.9 & 15.2 & 14.4 & 15.0 & 14.8 & 14.5 & 14.3 & 13.8 & 13.7 & 13.6 \\
\hline
\end{tabular}




\section{APPENDIX 2}

The dynamics of the shadow economy in EU-10 (as percentage of GDP) (source: www.Eurostat. com)

\begin{tabular}{|l|l|l|l|l|l|l|l|l|l|l|l|l|l|}
\hline State & 2003 & 2004 & 2005 & 2006 & 2007 & 2008 & 2009 & 2010 & 2011 & 2012 & 2013 & 2014 & 2015 \\
\hline $\begin{array}{l}\text { Slova- } \\
\text { kia }\end{array}$ & 18.4 & 18.2 & 17.6 & 17.3 & 16.8 & 16.0 & 16.8 & 16.4 & 16.0 & 15.5 & 15.0 & 14.6 & 14.1 \\
\hline $\begin{array}{l}\text { Czech } \\
\text { Rep. }\end{array}$ & 19.5 & 19.1 & 18.5 & 18.1 & 17.0 & 16.6 & 16.9 & 16.7 & 16.4 & 16.0 & 15.5 & 15.3 & 15.1 \\
\hline $\begin{array}{l}\text { Hunga- } \\
\text { ry }\end{array}$ & 25.0 & 24.7 & 24.5 & 24.4 & 23.7 & 23.0 & 23.5 & 23.3 & 22.8 & 22.5 & 22.1 & 21.6 & 21.9 \\
\hline $\begin{array}{l}\text { Slove- } \\
\text { nia }\end{array}$ & 26.7 & 26.5 & 26.0 & 25.8 & 24.7 & 24.0 & 24.6 & 24.3 & 24.1 & 23.6 & 23.1 & 23.5 & 23.3 \\
\hline Malta & 26.7 & 26.7 & 26.9 & 27.2 & 26.4 & 25.8 & 25.9 & 26.0 & 25.8 & 25.3 & 24.3 & 24.0 & 24.3 \\
\hline Poland & 27.7 & 27.4 & 27.1 & 26.8 & 26.0 & 25.3 & 25.9 & 25.4 & 25.0 & 24.4 & 23.8 & 23.5 & 23.3 \\
\hline Cyprus & 28.7 & 28.3 & 28.1 & 27.9 & 26.5 & 26.0 & 26.5 & 26.2 & 26.0 & 25.6 & 25.2 & 25.7 & 24.8 \\
\hline $\begin{array}{l}\text { Lithua- } \\
\text { nia }\end{array}$ & 32.0 & 31.7 & 31.1 & 30.6 & 29.7 & 29.1 & 29.6 & 29.7 & 29.0 & 28.5 & 28.0 & 27.1 & 25.8 \\
\hline Estonia & 30.7 & 20.8 & 20.2 & 29.6 & 29.5 & 29.0 & 29.6 & 29.3 & 28.6 & 28.2 & 27.6 & 27.1 & 26.2 \\
\hline Latvia & 30.4 & 30.0 & 28.5 & 29.0 & 27.5 & 26.5 & 27.1 & 27.3 & 26.5 & 26.1 & 25.5 & 24.7 & 23.6 \\
\hline $\begin{array}{l}\text { EU-10 } \\
\text { average }\end{array}$ & 26.6 & 25.3 & 24.9 & 25.7 & 24.8 & 24.1 & 24.6 & 24.5 & 24.0 & 23.6 & 23.0 & 22.7 & 22.2 \\
\hline
\end{tabular}

APPENDIX 3 The dynamics of the shadow economy in EU-3 (as percentage of GDP) (source: www.Eurostat.com)

\begin{tabular}{|l|l|l|l|l|l|l|l|l|l|l|l|l|l|}
\hline State & 2003 & 2004 & 2005 & 2006 & 2007 & 2008 & 2009 & 2010 & 2011 & 2012 & 2013 & 2014 & 2015 \\
\hline $\begin{array}{l}\text { Croa- } \\
\text { tia }\end{array}$ & 32.3 & 32.3 & 31.5 & 31.2 & 30.4 & 29.6 & 30.1 & 29.8 & 29.5 & 29.0 & 28.4 & 28.0 & 27.7 \\
\hline $\begin{array}{l}\text { Roma- } \\
\text { nia }\end{array}$ & 33.6 & 32.5 & 32.2 & 31.4 & 30.2 & 29.4 & 29.4 & 29.8 & 29.4 & 29.1 & 28.4 & 28.1 & 28.0 \\
\hline $\begin{array}{l}\text { Bulga- } \\
\text { ria }\end{array}$ & 35.9 & 35.3 & 34.4 & 34.0 & 32.7 & 32.1 & 32.5 & 32.6 & 32.3 & 31.9 & 31.2 & 31.0 & 30.6 \\
\hline $\begin{array}{l}\text { EU-3 } \\
\text { avera- } \\
\text { ge }\end{array}$ & 33.9 & 33.4 & 32.7 & 32.2 & 31.1 & 30.4 & 30.7 & 30.7 & 30.4 & 30.0 & 29.3 & 29.0 & 28.8 \\
\hline
\end{tabular}

